\title{
Література
}

1. Антонович Є.А. Декоративно-прикладне мистецтво / Є.А. Антонович, P.В. Захарчук-Чугай, М.Є. Станкевич. - Львів : Світ, 1992. - 272 с.

2. Борисова С. Етнодизайн як явище сучасної культури. [Електронний ресурс]. Режим доступу: http://www.nbuv.gov.ua>Portal/Soc_Gum/Gnvp/ 2011_54/4.pdf

3. Даниленко В.Я. Основи дизайну: [навч. посіб. ]/В.Я.Даниленко.-К.: IЗМН, 1996.- 92 с.

4. Вишивка Дрогобиччини. Традиції і сучасність / М.П. Кот /Альбом. - Львів: Інститут народознавства НАН України, 1999. - 107 с.

5. Скуратівський В.Т. Покуть : народознавчі матеріали /В.Т. Скуратівський/. - К. : Фірма Довіра, 1992. - 230 с.

6. Тимків Б.М. Роль етнодизайну в підготовці художників декоративно-прикладного мистецтва. - Наукові записки: Серія Педагогіка. - 2011. - №3. - С.171-176.

7. Українська минувшина: Ілюстрований етнографічний довідник. - 2-е вид. /А.П. Пономарьов, Л.Ф. Артюх, Т.В. Косміна та ін./ - К.: Либідь, 1994. - 256 с.

Стаття надійшла до редакції 23.05.2012 p.

УДК 378.78(07):004

Л. I. Варнавська,

кандидат пед. наук, ст. викладач, Криворізький педагогічний інститут ДВНЗ «Криворізький національний університет»

\section{КОМП'ЮТЕРНІ ТЕХНОЛОГІї: МОЖЛИВОСТІ ВИКОРИСТАННЯ В МУЗИЧНІЙ ОСВІТІ}

Варнавська Л. І. Комп 'ютерні технології: можливості використання в музичній освіті.

Актуальність матеріалу, викладеного в статті, зумовлена стрімким розвитком комп'ютерних технологій, поширенням їх застосування в науці, освіті, повсякденному житті. Питання необхідності використання засобів комп ютерних технологій у сучасному освітньому просторі, зокрема, в музичній освіті, перебувають у полі посиленої уваги багатьох педагогівмузикантів, потребують наукового підходу до иієї проблеми. Деякі засади використання засобів комп'ютерних технологій на уроках музики, розглянуті у статті, визначають спрямування їх застосування в музичній освіті.

Ключові слова: комп 'ютерні технології, навчально-виховний прочес, музична освіта.

Варнавская Л. И. Компьютерные технологии: возможности использования 6 музыкальном образовании.

Актуальность материала, изложенного в статье, обусловлена быстрым развитием компьютерных технологий, распространением их использованием в науке, образовании, повседневной жизни. Вопросы необходимости использования компьютерных технологий в современном образовательном пространстве, а именно, в музыкальном образовании тревожат многих педагогов-музыкантов, требуют научного подхода к этой проблеме. Некоторые вопросы использования средств компьютерных технологий на уроках музыки, рассмотренные в статье, определяют направление их использования в музыкальном образовании.

Ключевые слова: компьютерные технологии, учебно-воспитательный процесс, музыкальное образование.

Varnavskaya L. Computer technology: potential use for music education.

The actuality of the material, given in the paper, is caused by the rapid development of computer technologies, their widespread application in science, education and everyday life. The necessities of using the means of computer technologies in the modern informative world, in musical education to be exact, attract the attention of music teachers and require the scientific approach to this problem. Some of the computer technologies applications in music classes, viewed in the paper, define their wide potential in the process of teaching music.

Key words: computer technologies, educational process, musical education. 
Постановка проблеми. Під час переходу до високотехнологічного інформаційного суспільства, в якому якість людського потенціалу, рівень освіченості й культури всього населення набувають вирішального значення, застосування комп'ютерних засобів навчання стає важливим напрямком сучасної педагогіки.

У навчально-виховному процесі актуальним $є$ питання відбору інформації і правильного та вчасного ії подання, що дозволяє пожвавити процес навчання, надати йому динамізму, гнучкості, посилити його прикладну спрямованість. Застосування комп'ютерних технологій дозволяє змінити саму технологію навчання, зробити урок більш наочним та цікавим.

Комп’ютер забезпечує активізацію діяльності вчителя та учнів на уроці, сприяє здійсненню диференціації та індивідуалізації навчання, розвитку спеціальної або загальної обдарованості, формуванню знань, посилює міжпредметні зв'язки, що дає можливість покращити якість навчання.

Швидкий розвиток та використання інформаційних та комунікаційних технологій відкриває нові можливості та ставить нові завдання перед світовою спільнотою. Цифрова технологія зробила революцію, дозволила поєднати в цифровій формі текст, графічне та відео зображення, мовленевий та музичний супровід, на основі чого створюються нові засоби передачі знань та засоби навчання.

Останнім часом у педагогічній теорії та практиці здійснюється активний пошук шляхів удосконалення методів i форм навчання, проводяться інтенсивні дослідження з питань запровадження в навчальний процес засобів комп'ютерно-орієнтованих систем навчання, ведуться роботи в галузі змісту музичної освіти. Посилення тенденції принципу варіативності в навчанні та вихованні призводить до появи нових програм із музики для загальноосвітніх шкіл. У вітчизняній педагогіці продовжують нарощувати тенденції впровадження принципу варіативності не тільки в зміст виховання дітей, але й у галузі форм та методів музичної діяльності.

Ефективному використанню комп'ютера на уроках музики заважає невелика кількість програмного забезпечення; спеціалістів, які б могли запропонувати завдання для розвитку творчих здібностей у всіх компонентах уроку, спрямувати дітей у русло пошуку себе в течії класичної та сучасної музики.

Аналіз останніх досліджень і публікацій. Спираючись на положення Концепції загальної середньої освіти до закону України «Про загальну середню освіту» [3, с. 6], яка спрямована на реалізацію Національної доктрини розвитку освіти в Україні, враховуючи сучасні процеси в країні, предмети мистецької освіти розглядаються як універсальний засіб розвитку творчих здібностей молоді, іiі естетичних потреб та інтересів, а інформатизація освіти має спрямувати потребу у використанні комп'ютерних технологій у необхідне русло, оскільки комп'ютерні технології спрямовані на підготовку особистості інформаційного суспільства; формування вмінь працювати 3 інформацією; розвиток 
комунікаційних здібностей; формування дослідницьких умінь та умінь вибору оптимальних рішень; забезпечення великим обсягом якісної інформації.

Психолого-педагогічні аспекти використання нових комп'ютерних технологій у навчальному процесі розглядаються у працях М. Жалдака, В. Зінченка, І. Заболоцької, А. Медушевського та інших.

О. Тихомиров зауважує, що використання інформаційних технологій зумовлює суттєві зміни у психіці, перетворює пізнавальні й мотиваційноемоційні процеси, діяльність і спілкування людини, свідомість і міжособові взаємини [5].

Про ефективність упровадження нових комп'ютерних технологій у процес опанування дитиною різними видами мистецтва йдеться в дослідженнях педагогів-музикантів Н. Бергера, В. Варченко, В. Козліна, I. Регейло, I. Ткачука, О. Чайковської, В. Штепи, В. Янкул та інших.

Метою статті $\epsilon$ з'ясування особливостей музично-комп'ютерних технологій та їх використання на уроках музики в загальноосвітній школі.

Виклад основного матеріалу дослідження. Підхід до створення інформаційно-освітнього середовища має відображати не тільки підготовку сукупності адаптованого згідно 3 попитом користувача текстового та ілюстративного матеріалу, але й розроблення технологічної основи (методик, прийомів, сучасних навчальних засобів), які дозволяють проектувати та супроводжувати пізнавальну діяльність. Інформаційно-освітне середовище повинно безперервно змінюватися, враховувати індивідуальні особливості учня, коло його інтересів.

Успіх реалізації освітянських завдань у галузі музичної педагогіки визначається впровадженням у практику музичного навчання новітніх технологій і виховання нових підходів до його організації і змісту. Музичні уподобання учнів, особливо середнього та старшого шкільного віку, пов'язані з електронною музикою, і сучасний урок музики в школі мають відповідати вимогам часу.

Інформатизація суспільства змінила психологію учня. Діти, правильно навчені основам інформатики, будь-яку діяльність пов'язують із комп'ютером, і ця тенденція посилюється. Комп'ютеризація музичної освіти може стати додатковою мотивацією навчання музиці сучасного учня.

Науковці по-різному трактують поняття, пов'язане з використанням комп'ютерних технологій в освіті.

Аналіз наукової літератури надав нам змогу дійти висновку, що комп'ютерна технологія навчання являє собою комплекс методологічних, психолого-педагогічних, програмно-технічних та організаційних засобів, призначених для інтенсифікації пізнавальної діяльності (навчання), управління навчанням, розв'язання практичних завдань за допомогою комп'ютерної техніки.

Комп'ютерні технології, на нашу думку, містять у собі три складові: технічні пристрої, програмне й навчальне забезпечення. До сучасних технічних пристроїв належать принтер, сканер, модем, теле- та 
відеоапаратура, пристрої для перетворення інформації з однієї форми в іншу й т.ін. Комп'ютеризація освіти припускає розроблення навчального забезпечення педагогічного процесу на основі нових i традиційних інформаційних технологій. Необхідні програми, які управляють роботою на комп'ютері, що обслуговують цю роботу.

Використання комп'ютерних технологій не виключає традиційних форм навчання, заснованих на безпосередньому творчому спілкуванні, але створюють нові позитивні чинники в навчанні, зокрема, значне збільшення частки й ефективності самостійної роботи учнів.

Інтенсивний розвиток теоретичних засобів інформаційних технологій навчання надає дидактичні можливості, ефективність реалізації яких значною мірою залежить від рівня розвитку, дидактичної обгрунтованості й «технологічності» методичного забезпечення.

3-поміж найважливіших питань, які ставить перед музичною освітою використання комп'ютерних технологій, можна назвати такі:

- комп'ютер і система музичної освіти в цілому (сутність, мета, зміст музичної освіти й виховання в його багатоаспектності та єдності);

- комп'ютер і навчальні заняття (урок, лекція, індивідуальне заняття);

- теорія й практика складання музично-дидактичних комп’ютерних програм;

- напрямку розвитку спеціалізованих машин - помічників музикантів і педагогів.

Головна мета музично-педагогічної освіти - забезпечити вдосконалення особистості, виховання музичної, художньої культури. Звідси - необхідність розроблення музичних освітніх систем, спрямованих на систему розвитку особистості. Впровадження комп'ютера в навчальний процес у межах особистісно орієнтованої моделі навчання сприяє розвитку особистості, формує в неї потребу в самоосвіті, саморозвитку [1].

У процесі навчання учень має розуміти, що форми й характер спілкування 3 комп'ютером, так само, як і виконання необхідних аспектів програми, в основному регламентує він сам. У результаті визначальним для нього стає основне завдання всього процесу навчання, пов'язане з оволодінням знаннями, уміннями й навичками, необхідними для успішної музичної діяльності, з'являється стійкий інтерес до навчання й пізнавальні мотиви, формуються потреби в самонавчанні, саморозвитку, уміння самовизначатися в навчальній діяльності, усвідомлення особистої відповідальності в ній.

Практично у всіх учнів, незважаючи на дефіцит знань в області інформатики, підкреслюється позитивне вихідне ставлення до роботи на комп'ютері; підвищення якості освіти; зростання творчої самоповаги; зниження інформаційного перевантаження.

Навіть при невнадалому виконанні завдання в учнів спостерігається стійка позитивна мотивація протягом засвоєння програми. Виявлено виразний зв'язок між методом, за допомогою якого учень засвоював матеріал, i здатністю згадати (відновити) цей матеріал у пам'яті. Увага під час роботи 3 
музичною комп’ютерною програмою на базі мультимедіа, як правило, подвоюється, тому звільняється додатковий час на інші види діяльності.

На уроках музики вчитель може використовувати комп'ютер задля демонстрування й розкриття особливостей історії розвитку музичних інструментів; контролю знань, умінь і навичок із розділу «Теорія музики»у вигляді тестів; організації акомпанементу пісень у простих фактурних формах, добору гармонійного супроводу; оволодіння нотацією й основами музичної грамоти, а, також, для пояснення будь-якого матеріалу, де комп'ютерні технології відіграють роль наочності, що важливо для сприйняття та запам'ятовування на уроці.

Наявні музичні програми для роботи з комп’ютером на уроках музики, можна умовно поділити на декілька груп: музичний програвач, програма для співу караоке, музичний комп’ютер, музичні енциклопедії, музичні ігри.

У сучасних умовах, коли вчитель не завжди має можливість застосовувати готові програмні матеріали, найбільш зручним засобом для створення уроків із мультимедійним супроводом є програма Microsoft Power Point, яка $є$ особливо зручною під час подання нового матеріалу. Програма Power Point дозволяє поєднувати аудіо - та відеоматеріали в єдине ціле. Із цих позицій комп'ютер став універсальним засобом навчання, а зручність його використання допомагає організувати процес навчання раціонально й ефективно. Використання слайд-презентацій, фотоматеріалів і репродукцій у цій програмі дає можливості для викладання музичної літератури, а робота зі звуковими редакторами дозволяє записувати, редагувати й обробляти звук, компонувати фрагменти музичних творів для створення аудіо-альбомів, які можна використовувати на уроках музичного мистецтва.

Педагогічний програмний засіб «Музичне мистецтво» розроблений відповідно до програми для загальноосвітніх навчальних закладів «Музика» (1-4 класи) (укл. О. Ростовський, Л. Хлєбникова, Р. Марченко), надає можливості під час вивчення та виконання пісень користуватися програмою караоке, при подачі нового матеріалу застосовувати казки, легенди, історичні факти у відео форматі при підтриманні музичного супроводу. Мультимедійний посібник орієнтований на сучасні форми навчання із забезпеченням сумісності 3 традиційними методами та прийомами навчання в повній відповідності 3 документами, що регламентують зміст освіти. У цій програмі представлено багато інформаційного та ілюстративного матеріалу для школярів. Усі вони супроводжуються відео сюжетами. Для старших класів класичну музику представлено розповідями про композиторів, їхню творчість.

Теми, запропоновані програмою по предмету «Музика», інтегруються 3 курсом інформатики, переплітаючись у дві основні лінії - інформаційну й творчу, що відповідає вимогам сучасної освіти. 3 усього вищесказаного можна зробити висновок: чим раніше ми почнемо творчий розвиток дитини за допомогою засобів комп'ютерних технологій, тим скоріше учень почне інтегруватися до сучасного навчального процесу. 
Висновки. Застосування комп'ютерних технологій у музичній освіті здійснюється для розв'язання мистецтвознавчих, педагогічних, інформаційнокомунікаційних завдань. Використання музичних комп'ютерних технологій сприяє модернізації навчального процесу в загальноосвітній школі, надає змогу залучати дітей до створення творчих робіт, оформлення результатів роботи за певними темами у вигляді різних проектів, пошукової роботи під час вивчення народної творчості, української музичної культури, творчості композиторів світу.

\section{Література}

1. Беспалов П. В. Компьютерная компетентность в контексте личностно ориентированного обучения / П. Беспалов // Педагогика. - 2003. - № 4. - С. 41-45.

2. Державний стандарт базової i повної загальної середньої освіти // Інформаційний збірник Міністерства освіти і науки України. - 2004. - № 1-2. - С. 5-60.

3. Закон України «Про загальну середню освіту» // Освіта України. - № 117. 1998. - C. 6 .

4. Затямина Т. Компьютерные технологии на уроке музыки / Т. Затямина // Искусство в школе. - 2006. - № 5. - С. 41-43.

5. Тихомиров О. К. Психология и информатика. Социальные и методологические проблемы информатики, вычислительной техники и средств автоматизации (материалы «Круглого стола») / О. К. Тихомиров // Вопросы философии. - 1986. - № 9. - С. 110-111.

Стаття надійшла до редакції 19.05.2012 p.

УДК: $378.14+378.2+378.18$

В. В. Нестеренко, кандидат пед. наук, доцент, Південноукраӥнський національний університет ім. К.Д. Ушинського

\section{ДИДАКТИЧНІ УМОВИ УПРАВЛІННЯ САМОСТІЙНОЮ НАВЧАЛЬНОЮ ДІЯЛЬНІСТЮ СТУДЕНТІВ ЗАОЧНОЇ ФОРМИ НАВЧАННЯ}

Нестеренко В. В. Дидактичні умови управління самостійною навчальною діяльністю студентів заочної форми навчання.

У статті розглянуто дидактичні умови, які сприяють управлінню самостійною навчальною діяльністю студентів заочної форми навчання. Описано підходи, щуо складають методологічну основу дидактичних умов управління самостійною навчальною діяльністю студентів-заочників.

Ключові слова:дидактичні умови, навчальна діяльність, студенти-заочники, підходи, управління самостійною навчальною діяльністю.

Нестеренко В. В. Дидактические условия управления самостоятельной учебной деятельностью студентов заочной формы обучения.

В статье рассматриваются дидактические условия, которые способствуют управлению самостоятельной учебной деятельностью студентов заочной формы обучения. Описань подходы, которые составляют методологическую основу дидактических условий управления самостоятельной учебной деятельностью студентов-заочников.

Ключевые слова: дидактические условия, учебная деятельность, студенты-заочники, подходы, управление самостоятельной учебной деятельностью.

Nesterenko V. Teaching self-management training conditions for the activities part-time students. 